\title{
Laser Materials Fabrication and Joining
}

\author{
Giuseppe Casalino
}

Dip. di Meccanica, Matematica e Management, DMMM-Polytechnic University of Bari, Via Orabona 4, 70125 Bari, Italy; giuseppe.casalino@poliba.it

Received: 6 June 2020; Accepted: 16 June 2020; Published: 22 June 2020

\begin{abstract}
This laser special issue has brought together academic scientists, researchers and laser manufacturers for a share of their experiences on recent progress in laser science and technology in the fields of laser materials processing for manufacturing. The papers cover advances in laser materials fabrication and joining of emerging materials, their fabrication and application.
\end{abstract}

Keywords: laser manufacturing; experiments; numerical simulation; laser material interaction

Laser-based manufacturing has increased dramatically in many different industries with unprecedented precision, efficiency and variety in materials processing [1]. High flexibility, efficiency, reproducible adjustability of processing parameters, and excellent quality of processed products are the main advantages that are provided by the laser-based technologies, which have opened the door to previously non-existent processes like direct metal deposition, laser sintering and melting, and laser powder welding [2-4].

This Special Issue concerns the application of the laser technology to welding advanced materials and dissimilar joints, along with additive fabrication, material trepanning, composite pre-treatment, surface treatment, and laser component fabrication. The aims of the papers of this Special Issue are to raise the scientific and technical attention and interest for laser material processing. In more detail, the presented papers deal with the following subjects.

The hybrid laser-MAG (metal active gas) welding process of twinning-induced plasticity and dual-phase steels with austenitic stainless steel (AISI316) was simulated by means of a thermo-mechanical model, which was developed using the finite element method [5].

The microstructural and mechanical properties of laser-tungsten inert gas hybrid welding of $\mathrm{Mg}$ alloy sheets for automobiles were investigated including AZ31 and ME21, AZ31 and AZ31, ME21 and ME21 [6].

The thermal efficiency analysis of the Laser-Assisted Plasma Arc Welding of AISI 304 Stainless was related to the melting efficiency for different sizes of the heat sources [7].

Titanium and Aluminum alloys were welded using the so-called off-set technique. The effects of focus and off-set distance of the laser beam on the weldability of grade 5 titanium to 6061 Aluminum alloy dissimilar butt weld were assessed [8].

The 10-mm thick high-yield-point steel S700MC was tested for disc laser welding for single- and double-sided welding [9].

A concise index of some governing factors with a potential operational use was proposed for Inconel 718 laser powder bed fusion. It was called volumetric energy density [10].

Samples of a WC/Co/Cr composite powder were fabricated and characterized in terms of density, defects, microstructure and hardness [11].

A comprehensive numerical model for the process of laser-assisted deposition of Aluminum alloy 2024 was built to assess the most effective reference shape to feed the simulation as a function of the governing factors in advance [12]. 
The applicability of laser-assisted synthesis for producing high-density $\mathrm{Cu}-\mathrm{Al}-\mathrm{Ni}$ alloys with shape memory characteristics was studied with the goal of further development towards a method of additive manufacturing of large-sized $\mathrm{Cu}$-based shape memory alloys [13].

Laser surface transformation hardening of AISI 4130 was investigated by a Nd:YAG pulsed laser. Laser focal height, pulse width, scanning speed, and power varied during the experiments [14].

Laser shock processing was utilized to strengthen the cavitation erosion resistance of austenitic stainless-steel laser weldments [15].

A semi-water-immersed laser micro-trepanning process was investigated with alumina ceramics as the target material. The performance was assessed and compared with the direct laser trepanning method [16].

An experimental investigation of the machining performance of the direct and chemical-assisted picosecond laser trepanning of single crystalline silicon was conducted to assess the machining method [17].

Using different laser sources, a composite aerospace prepreg system underwent laser-based bonding pre-treatment with analytical tests and after-bond mechanical testing to determine the bonding ability of the specimen treatment [18].

The silica is widely applied in the modern laser system. A highly-efficient and low-damaging lapping process model was presented for the optimization of the finishing operation of silica [19].

Funding: This research received no external funding.

Acknowledgments: Special thanks go to the authors for their contributions and the reviewers for their valuable comments. I would also like to thank a lot the managing editor Wency Zhang and the staff of the editorial office for their advice and support.

Conflicts of Interest: The author declares no conflicts of interest.

\section{References}

1. Rashkovets, M.; Mazzarisi, M.; Nikulina, A.A.; Casalino, G. Analysis of laser direct stainless steel powder deposition on Ti6Al4V substrate. Mater. Lett. 2020, 274, 128064. [CrossRef]

2. Campanelli, S.L.; Angelastro, A.; Signorile, C.G.; Casalino, G. Investigation on direct laser powder deposition of $18 \mathrm{Ni}$ (300) marage steel using mathematical model and experimental characterization. Int. J. Adv. Manuf. Technol. 2017, 89, 885-895. [CrossRef]

3. Casalino, G.; Campanelli, S.L.; Contuzzi, N.; Ludovico, A.D. Experimental investigation and statistical optimisation of the selective laser melting process of a maraging steel. Opt. Laser Technol. 2015, 65, 151-158. [CrossRef]

4. Errico, V.; Campanelli, S.L.; Angelastro, A.; Mazzarisi, M.; Casalino, G. On the feasibility of AISI 304 stainless steel laser welding with metal powder. J. Manuf. Process. 2020, 56, 96-105. [CrossRef]

5. Perulli, P.; Dassisti, M.; Casalino, G. Thermo-Mechanical Simulation of Hybrid Welding of DP/AISI 316 and TWIP/AISI 316 Dissimilar Weld. Materials 2020, 13, 2088. [CrossRef] [PubMed]

6. Li, T.; Song, G.; Zhang, Z.; Liu, L. Mechanical Properties and Microstructures of Laser-TIG Welded ME21 Rare Earth Mg Alloy. Materials 2019, 12, 2188. [CrossRef] [PubMed]

7. Hipp, D.; Mahrle, A.; Beyer, E.; Jäckel, S.; Hertel, M.; Füssel, U. Thermal Efficiency Analysis for Laser-Assisted Plasma Arc Welding of AISI 304 Stainless Steel. Materials 2019, 12, 1460. [CrossRef] [PubMed]

8. Casalino, G.; D'Ostuni, S.; Guglielmi, P.; Leo, P.; Palumbo, G.; Piccininni, A. Off-Set and Focus Effects on Grade 5 Titanium to 6061 Aluminum Alloy Fiber Laser Weld. Materials 2018, 11, 2337. [CrossRef] [PubMed]

9. Górka, J. Assessment of the Weldability of T-Welded Joints in $10 \mathrm{~mm}$ Thick TMCP Steel Using Laser Beam. Materials 2018, 11, 1192. [CrossRef] [PubMed]

10. Caiazzo, F.; Alfieri, V.; Casalino, G. On the Relevance of Volumetric Energy Density in the Investigation of Inconel 718 Laser Powder Bed Fusion. Materials 2020, 13, 538. [CrossRef] [PubMed]

11. Campanelli, S.L.; Contuzzi, N.; Posa, P.; Angelastro, A. Printability and Microstructure of Selective Laser Melting of WC/Co/Cr Powder. Materials 2019, 12, 2397. [CrossRef] [PubMed] 
12. Caiazzo, F.; Alfieri, V. Simulation of Laser-assisted Directed Energy Deposition of Aluminum Powder: Prediction of Geometry and Temperature Evolution. Materials 2019, 12, 2100. [CrossRef] [PubMed]

13. Niedbalski, S.; Durán, A.; Walczak, M.; Ramos-Grez, J.A. Laser-Assisted Synthesis of Cu-Al-Ni Shape Memory Alloys: Effect of Inert Gas Pressure and Ni Content. Materials 2019, 12, 794. [CrossRef] [PubMed]

14. Casalino, G.; Moradi, M.; Moghadam, M.K.; Khorram, A.; Perulli, P. Experimental and Numerical Study of AISI 4130 Steel Surface Hardening by Pulsed Nd:YAG Laser. Materials 2019, 12, 3136. [CrossRef] [PubMed]

15. Zhang, L.; Liu, Y.-H.; Luo, K.-Y.; Zhang, Y.-K.; Zhao, Y.; Huang, J.-Y.; Wu, X.-D.; Zhou, C. Tensile Property of ANSI 304 Stainless Steel Weldments Subjected to Cavitation Erosion Based on Treatment of Laser Shock Processing. Materials 2018, 11, 805. [CrossRef] [PubMed]

16. Ma, Q.; Zhu, H.; Zhang, Z.; Xu, K.; Dai, X.; Zhu, S.; Wang, A. An Investigation into Picosecond Laser Micro-Trepanning of Alumina Ceramics Employing a Semi-Water-Immersed Scheme. Materials 2019, 12, 1812. [CrossRef] [PubMed]

17. Zhu, H.; Zhang, Z.; Xu, K.; Xu, J.; Zhu, S.; Wang, A.; Qi, H. Performance Evaluation and Comparison between Direct and Chemical-Assisted Picosecond Laser Micro-Trepanning of Single Crystalline Silicon. Materials 2019, 12, 41. [CrossRef] [PubMed]

18. Blass, D.; Nyga, S.; Jungbluth, B.; Hoffmann, H.D.; Dilger, K. Composite Bonding Pre-Treatment with Laser Radiation of $3 \mu \mathrm{m}$ Wavelength: Comparison with Conventional Laser Sources. Materials 2018, 11, 1216. [CrossRef] [PubMed]

19. Song, C.; Shi, F.; Zhang, W.; Lin, Z.; Lin, Y. High-Efficiency and Low-Damage Lapping Process Optimization. Materials 2020, 13, 569. [CrossRef] [PubMed]

(C) 2020 by the author. Licensee MDPI, Basel, Switzerland. This article is an open access article distributed under the terms and conditions of the Creative Commons Attribution (CC BY) license (http://creativecommons.org/licenses/by/4.0/). 